\title{
HOW COME A LIBERAL STILL BELIEVES IN DEMOCRACY? A RIDDLE OF POLITICS AND FAITH
}

\author{
About the book by James Miller \\ Can Democracy Work? A Short History of a Radical Idea from Ancient Athens \\ to Our World
}

Farrar, Straus \& Giroux, New York, 2018.

\author{
Krešimir Petković \\ Faculty of Political Science \\ University of Zagreb \\ E-mail:kpetkovic@fpzg.hr
}

\author{
DOI: $10.20901 / a n .15 .10$ \\ Essay \\ Accepted: December 2018
}

\begin{abstract}
This critical essay deals with the book Can Democracy Work? by James MiIler, which, warning of the problems of democratic politics, retains democratic faith. By combining political science and historiography, and intertwining the history of ideas with political biography in portraying different episodes in the history of democracy, the book seeks to give insight into the riddle of democracy. This riddle is exhibited in various theoretical and practical tensions: between the Rousseauian demand for sovereignty of the people and the general will on the one hand, and the Platonistic epistemic skepticism about the ability of the people to decide and the political demands of liberalism on the other; between the need to control the rulers and the political-economic dynamics of corruption and clientelism incited by democratic politics; between rebellion against the elites as a species of functional political hygiene in a polity, and uncertainty of outcomes brought by the inherent instability of democracy and its aptitude to excess; and between the seeming inevitability of elections and their cooptational trap. Between the liberalism of fear à la Judith Shklar and the thrills of populism à la Chantal Mouffe, the author retains democratic faith - a political version of Kierkegaardian existentialism which goes beyond the undecided, forever doubting reflection and a political good that is shared with others, in spite of the uncertainties of public opinion and the ascertained questionability of civic virtue in the open field of the political in history.
\end{abstract}

Keywords democracy, liberalism, riddle, genealogy, populism, public opinion

I.

In late August 2018, Darko Milinović, former Croatian Minister of Health and the Governor of Ličko-senjska County, mobilized local party members for an unusual quest. Four buses from the prov- ince, with about 200 people according to the media reports - the party members of the Croatian Democratic Community (HDZ), the leading party in the ruling coalition - arrived in Zagreb in front of the national party headquarters, to 
protest the issues concerning intraparty elections and politics. Lovro Kuščević, the Minister of Public Administration and the political secretary of HDZ, accused the organizers for manipulation, stating that "they don't know democracy". ${ }^{1}$ On the other hand, Milinović, who was expelled from the party, called the procedure of his deletion "unashamedly undemocratic". ${ }^{2}$

A relatively insignificant event from contemporary Croatian politics still points to big issues, both in conceptual history of democracy and the contemporary political discourse obsessed with it. Does democracy refer to the tidy procedure of aggregating individual wills or to the fuzzy expressions of collective will on various levels of political life? And in terms of Begriffsgeschichte, where Carl Schmitt, an astute critic of liberal democracy, diagnosed the times of neutralizations and depoliticizations, the question is how come that the same actions are called (un)democratic by political opponents and antagonists, typically in the situations when specific criteria of a meritocratic or professional system to judge one's actions are absent? It seems that in the clashes of political discourse everyone likes to have "democracy" on his side.

But what is "democracy" after all? Aside of the questions of grass roots actions and institutional procedures, is it applicable solely to demos or to the notoriously oligarchic parties as well, the particular political organizations competing in the political arena with their general programs claiming the knowledge of the common good? What does

1 "Milinovićev čin podijelio HDZ, Kuščević za njegovo izbacivanje iz stranke, no Kujundžić poručuje: 'Ne treba mahati sankcijama'", dnevnik.hr, August 30 2018.

2 "Zaštitari na izborima: 'Koliko je trebalo biti demokracije na ovim izborima?", dnevnik.hr, September $9^{\text {th }} 2018$. democracy mean today and how is this associated to what it has meant in various historical, cultural and geographical settings? Can it work?

While the answers to the former questions demand careful empirical analysis and theoretical prowess, the last one also implies a telos, a purpose, a vision of good life, which should be attained by democratic politics. Discussions of such big questions reveal not only one's ability to analyze but thus also reveal, so to say, one's normative persona. What does one aspire and what does one loathe? What does one inadvertently or voluntarily hide and reveal? What does one hope for or believe in? The question of democracy, today as ever, is not only a question of political analysis, but also of values, identity, and even esthetics and eschatology of an author discussing politics. Histories and evaluations of democracy tackling these big and ages old questions that haunt political thought at least from the Greek times, could very well offer a full confession of a zoon politikon or, more humanely, a homo politicus, striving for the beautiful and the good in a political community. Or, perhaps, a less optimistic confession of the frailness of an attempt to offer a vindication of democracy in the context of an inability to provide a convincing answer about its future based on levelheaded evaluation of its historical experience.

II.

What if James Miller, a New School Professor and an historian of ideas, set out to answer these questions, offering a history of democracy as an idea and historical practice? Well, he did, and his interesting and sincere book, encompassing about 300 pages (about 250 without endnotes), confirms this hunch: the book is at the same time a political analysis, a biography and a confession of faith. Miller, a former rock'n'roll crit- 
ic and Foucault's biographer who wrote on the lives of philosophers, is not new to the subject. It's his third book about democracy, the first one being Rousseau: Dreamer of Democracy (1984) published by Yale University Press, while the second one, Democracy Is in the Streets (Simon \& Schuster 1987), republished by Harvard University Press (1994), dealt with the "miracles" and "monsters" of the New Left, vividly portraying radical leftism in the US, one of the Western polities that also produced its picturesque soixante-huitards (Miller did partake in the said political carnivals). In other words, the author has something to say on the subject of democracy, judging both from his experience and his scholarly expertise and work.

Can democracy work? is a work of maturity. It puts youth ideals on the trial of skepticism that one acquires with age, when one is more or less retired from the streets, rarely dreaming of personal future prospects and mostly looking back to reassess the past. The book goes beyond the sometimes barren and abstract language of contemporary political theory. Miller's knowledge of the history of political ideas is paired with the stylistic qualities of prose and the richness of language. He interveawes the personal and the political in his narrative. The book comes off neither as an empirically banal, recycling textbook interpretations, nor as a dullish pamphlet. As in the case of the lives of philosophers from Miller's Examined Lives (Picador, 2012), the well-researched episodes have many intriguing facets and, although there are passages that do not lack overly archaic pathos, Miller does not proselytize: a seemingly Manichean distribution of roles is usually put down to earth by a skeptical nod or a touch of (auto)irony.

The episodes from the history of democracy are recounted in five chapters, with each title summing the different concept of democracy emerging in the political history of the West. The book also provides introductory synopses of the chapters, stylistically evocative of picaresque novels (an old Spanish genre, precisely recounting life histories of the likeable scapegraces). As the synopsis of "Prelude" has it, the book deals with the riddle of democracy (one of the working titles of the book was "The Riddle of Democracy"): "The riddle posed, and some answers explored, in five historical essays" (vi). And the collaged pillar on the covers already reflects the variety of the chosen historical episodes: the assembled artwork contains both bits of Greek alphabet and violent Delacroix's Liberty Leading the People on the top the famous lady with a flag, a bayoneted musket and a nipple, paying homage to the French July Revolution of 1830. In the following sections, I will lead the potential reader through the content of the book's introduction (the mentioned "Prelude") and its chapters to come to its conclusion (the "Coda"), quite unsettling for the uncritical proponents of democracy. The readers will ultimately have to decide for themselves if the book solves the riddle posed suggested already in the abstract of the essay and the strange lyrics, ironically evoked in its epigraph. On my part, I shall offer some reflections on the titular question associated both with democracy and with the profile of the author as a proponent of political hope, still willing to use Whitman and Brecht in his exalted epigraphs albeit all the skepticism he tends to express.

III.

The introduction provides the usual distinctions, modest disclaimers and reasonable caveats. It correctly states that liberalism and democracy are terms "almost hopelessly conflated and confused" (14) in the contemporary politi- 
cal discourse; that the story recounted is Eurocentric and that the choice of the cases highly selective. The work is, as the author confesses, a specific product of an epistemological tradition of writing intellectual history and of a political tradition of democracy he was raised in. Although Miller is aware of the tensions and faults of that tradition, he can still write the introduction as a proud American, raised on Whitman's Democratic Vistas, claiming that he is "struck by the progress" they "have made as a nation", further expressing his pride with "the polyglot expansion of" American "citizenry as a whole, and the generosity with which Americans, at their best, have conceived of popular sovereignty in pluralistic terms": in Miller's eyes, "the United States has evolved into the world's most striking ongoing experiment in cosmopolitan self-governance" (17).

The introduction explicitly poses the seemingly simple question "What is democracy?" It makes some sense to recount Miller's preliminary suggestion of an answer before going to specific episodes. He does not provide an abstract scholastic definition but points to a political tension, present both in my vignette from the European periphery and in the episodes analyzed. This tension appears within an ambitious swathe of a culture and a way of life. It is framed as a doubt and followed by a paradox:

Perhaps, as Tocqueville and others have argued, democracy isn't merely a form of government, it is also a way of life, and a shared faith, instantiated in other forms of association, in modes of thought and belief, in the attitudes and inclinations of individuals who have absorbed a kind of democratic temperament. But how can democratic habits of association, conduct, and conviction survive in a setting where democracy as a poli- tical form is honored mainly in the breach? (7)

I see two things important to understand Miller's political effort suggested in the quoted paragraph. Following Tocqueville, whose historical analysis (even if he wasn't bashful in his generalizations, as Miller observes) became a sort of a gospel of American democracy, democracy is normatively posited as a sort of vibrant political culture of a collective that shares common future and faith. It refers, then, to the cultivation of a finer temperament, contrasted with the often brutal and cruel mob instincts, diagnosed and theorized by Gustave Le Bon's Psychologie des foules. It appears in the realm of political sociology against the psychology of the masses ignited by irresponsible, charlatan or deranged populist leaders. This mechanism of manipulation is in Miller's narrative associated with the "bad guys" of the chosen episodes from Ancient Greece to Jacksonian democracy in the US, providing it with a moralist quasi-Manichean touch and at the same time supplying it with one of the important leitmotifs that hold the episodes together (another one may be a historically grounded premonition about the limited lifetime of any given democracy).

To be sure, in Miller's narrative, it's never a haughty aristocratic pose despising "the great unwashed". His contempt is reserved for the populist irresponsibility, charlatanry, demagoguery and scheming that gives mobs a mandate to do harm, and that so easily transforms itself to despotism when in power. And this seems to be morally right, about as Montaigne's essay against cruelty. However, there is more to the tension between political life and political form haunting democratic life, to which I will have to return at the end.

IV. 
The title of the first chapter, "A Closed Community of Self-Governing Citizens," summarizes, somewhat idealistically, what democracy meant in Greece. As the Greeks had it: "'Our city is called a democracy because it is governed by the many, not the few"' is "one of the earliest, and simplest, definitions of the new political form" (30), that is relevant to this day. Many of the problems and dilemmas of today's democracy were also there at the beginning, in Athens, where the term and the practice was born for the Western political history, before the large democratic hiatus filled by monarchic political form: nativism versus the outsiders; military service forging fraternity and citizen spirit, i.e. "democracy based on citizen-soldiers poised to shed blood" (52), as later in France; masses manipulated by the demagogues, all together paired with a lack of rights in specifically modern liberal constitutional sense, and the largely forgotten lottery as, when one thinks of it, logical method of choice, at least if political equality is understood as an empirical fact.

Miller notes the fact that "only a small fraction of the Athenian population participated in politics" and this came in hand with "[t]he myth of Athenian autochthony - a strong form of nativism, stressing that citizens must spring from the land" which "enabled even the poorest citizen to regard himself as wellborn" (29). Although he uses all the caveats, Miller is keen to see the parallels between the Greek and the French case, Athenian democracy and the republic established in the course of the French Revolution, while further democratic episodes in his narrative also demonstrate similar tensions present already in Athens. Among other things, he mentions Josiah Ober's comparison of the Athenian uprising of 508 B.C. and the storming of the Bastille (24), the volatility of the will of the demos - the "citizens in assembly were perfectly free to reject previously approved laws, even to establish completely new institutions" (36) - and the political problems associated with "empowering an impoverished multitude" (37).

Thucydides' skepticism concerning the "demos in action," ignited and moved by popular leaders such as Cleon (38), feels as a contemporary if not a timeless warning in Miller's narrative, especially when affiliated with David Runciman's general remarks echoing Plato - of how "democracy pandered to desire": "It gave people what they wanted day to day, but it did nothing to make sure they wanted the right things. It had no capacity for wisdom, for difficult decisions, or for hard truths. Democracies were founded on flattery and lies" (42). To this, reader can add Miller's skepticism towards Arendt's idealistic visions of Greek democracy and to her intellectual progeny of armchair philosophers (44), and an affirmative nod to Paul Cartledge's summary of Antic democratic experience as "participatory democracy with a vengeance" (48). After all, the big political invention did not end up in glory but in vulnerable and dependent shrinking oligarchies that withered away to be incorporated into larger empires.

\section{V.}

The motif of a republican military service introduces the French case, recounted under the title "A Revolutionary Assertion of Popular Sovereignty": "the French Revolution had made it clear that Athens would not be the last example of a democracy based on citizen-soldiers poised to shed blood. Fraternity, solidarity, and the kinds of virtues forged through conflict and struggle would prove alluring for a number of subsequent democrats of different persuasions" (52). Not surprisingly, Machiavelli's ideas also appear in Miller's analysis: the gre- 
at Florentine political thinker's claims that armed people make a better army than shifty mercenaries and, even if very cautiously, the controversial concept of "Machiavellian democracy". However, the basic structure of the chapter, if one omits few details and focuses instead on the distribution of forces struggling in the clash of political good and evil, is almost opera-like in its simplicity; or, if one really wants to stretch the comparisons and put aside the many differences that spring from the usage of Orwell's satirical October allegory, it is the old Major, Napoleon and Snowball, transposed from an animal farm to the French Revolution. Let me explain this strange association.

Rousseau, "the Genevan-born sage" (whose Social Contract was banned in his native republic, since it was judged to be dangerous for the Genevan constitution) prophesized "the century of revolutions" (56). His love for the people was recognized by Robespierre, who uttered many ambivalent and contradictory ideas about politics - e.g. Miller writes on his "complete about-face from the ultrademocratic views" (87). But as a policy practitioner, Robespierre wasn't that ambivalent. In the course of the French Revolution, democratic ideas have correlated with violent impulses, expressed by the often blood-thirsty sans-culottes (in Miller's opinion wrongly exculpated by Arendt). Rousseau's ultimate political ideals, freedom and equality, and his vision of a republic with citizens as sovereign, making laws that express general will, ended up (or, more exactly, began) with "a carnival of atrocities" (72). As the very end of the chapter has it, the French Revolution was "a hecatomb on a grand scale" (89). Unlike Foucault - who was ambivalent, if not cynical, when he discussed the bloody assertions of revolutionary power with Chomsky in the early 1970s - and Žižek much later, Miller abhors revolutionary bloodshed (like Chateaubriand in his days), pointing to the September Massacres of 1792 and other episodes of "indiscriminate slaughter" (74). However, this is not only an aesthetic sentiment, but a theoretical claim. Miller nods positively to Simon Schama, who posits an inherent tie between revolution and bloodshed by the masses, those by definition being opposed to the checks and balances of a moderate rational government: "If Schama is correct - and I believe he is," writes Miller, "then previous scholars have been wrong to imply that the ardent desire of ordinary people for public freedom can be separated, in fact, from their willingness to use force in its pursuit" (72).

If Rousseau's vision can be vaguely associated with that of the old Major (Marx), and if Robespierre, the terror and the violent masses, can be associated with Napoleon (the hog not the general), referring in Orwell's narrative to Stalin and the purges, who is then Snowball (Trotsky, hammered to death in Mexico) of the French Revolution? Maybe we could find one on closer inspection, but he would not be that important for Miller's narrative. The calls for permanent revolution cannot be compared with the project of a rational liberal-democratic constitution, and it is not that clear that Snowball is a good guy, but there is a good guy in Miller's chapter though. It is Marquis de Condorcet, a "mathematical prodigy" and "methodological individualist in the tradition of Adam Smith" (75), who already then was a proponent of women rights, an enemy of slavery, and an extreme skeptic in the matters of religion, as a posthumous biographical note put it (76). Condorcet, an author interested in the finesses of l'arthimétique politique, was instrumental in translating the obscure idea about pluses, minuses and the 
general will from the Social Contract into French constitutional order. His mission was to "rationalize the drafting of laws for the public good" (75). His problem? "He knew perfectly well that his fondest hopes for an enlightened regime of political freedom had been hijacked by Robespierre and a few other fanatics of virtue" (88). His destiny? Although he did not end up guillotined as Robespierre himself, after a period of hiding, Condorcet was imprisoned. He died in his cell, poisoned, perhaps taking poison voluntarily like Socrates, or simply from stroke: it is not clear to this day.

\section{VI.}

The next chapter discusses Miller's own polity, under the title "A Commercial Republic of Free Individuals," that sums up the ideas of the founding fathers - the same thing that the Canadian interpreter of Hobbes and Locke C. B. Macpherson, called "possessive individualism". There is of course much more in the complex story about the nascence of the American republic, since, after all, "Republican Rome was their model, not Periclean Athens" (92), and Madisonian distrust of the people, the unconstrained popular sovereignty without checks and balances, was there from the beginning, echoing in Miller's own doubts about the real status of democracy in America. In other words, the "characteristically guarded American approach to popular sovereignty made elections a crucial feature of the new regime - and struggles over the right to vote a focus of subsequent efforts to ensure that all Americans, regardless of race, gender, or wealth, felt they had standing in a republic of equals" (92).

Miller's versatility in combining history of ideas and biographical work finds its focus in several important persons that helped to shape American democratic imaginary formed in $18^{\text {th }}$ and $19^{\text {th }}$ century. It's a motley array of revolutionaries, presidents, ethnographically disposed aristocrats, transcendentalists and poets: Paine, Jackson, Tocqueville, Emerson, and Whitman. Thomas Paine, the author of the pamphlet Common Sense, advocated simple government accountable to the people, a "commonwealth of self-reliant individuals" (93). Society, not the state (as in Hegel), was the place of freedom and happiness for him, a place of voluntary associations and organizations and market transactions between individuals, i.e. the place of "commerce" (96), but Miller reminds the reader that Paine later advocated some rudimentary forms of social policy, such as grants and pensions funded by an estate tax (97).

If Paine is there to account for the chapter title and the early theoretical foundations of American polity, Jackson is there to demonstrate the noxious populist dynamics as a recurring interest of Miller's democratic analysis. Miller is not lonely in not being too fond of Jackson, citing, among many other things, Jackson's support of Indian resettlement, "America's unique contribution to the art of 'ethnic cleansing'" (110), and ignoring the rule of law embodied in the Supreme Court's decisions. Assuming the role of a national "tribune," Miller's Jackson is a figure similar to Athenian demagogues, mobilizing commoners against the elite in a new setting of a grand scale federal polity, "trying to turn the quadrennial vote for the most powerful figure in the federal government into a national plebiscite" (112). Miller's interpretation of Jackson does not only function as a critique of Trump's presidency thus far, in the ruse of an historical analysis; it also helps to further profile Miller's normative understanding of democracy, juxtaposing a culture of emancipated individuals - where there are no slaves, but also no masters, according 
to Lincoln's definition (118) - with the authoritarian patterns of populist politics. Jackson is not to be revered: "one is struck by the discrepancy between what Jackson, based on the evidence, seems actually to have accomplished in the way of democratizing reforms, and the outsize role he assumes in the national lore (at least the lore I was taught growing up about this putative hero of the common man)" (112). By the way, Miller's analysis of the case of Thomas Wilson Dorr, and the so-called Dorr Rebellion, associated with the struggle for suffrage in Rhode Island, demonstrates similar sentiments: a loathing of populism and all "venal demagogues running on disingenuous policy platforms" (124).

De Tocqueville, who was in a mission with de Beaumont to inspect the American prison system, met Jackson and was not too impressed with the finesse of his character and abilities. Tocqueville based his insights in the observations of "Jacksonian democracy", a term Miller himself uses in (scare) quotes. However, Miller does not seem to be impressed with conclusions of the author, "regarded as an uncanny prophet" (116), overprone to generalize. It is not only Tocqueville's misfires concerning the issues of universal suffrage and its practices - Miller seems to like Lijphart's suggestions to make voting in the US obligatory, not a right, but a "civic duty" (123) - that did not stand the test of time in Miller's opinion. Unlike Adorno, another American visitor much later, Miller did not find Tocqueville's "worries about conformism" reasonable: "the United States had already begun to elaborate a distinctively clamorous style of public culture" and "an emergent culture industry made it both possible - and profitable - to market cultural artifacts that strove to satisfy the otherwise frustrated yearnings of ordinary Americans to be regarded as free and equal individuals, with cultural tastes as worthy and legitimate as those of any European aristocrat" (124).

Enter Emerson and Whitman, authors immensely important to understand Miller's writings on democracy in America. The first one "provided a quasi-religious sanction for the American cult of individualism" which justifies the usage of the term "Emersonian ideology" as opposed to the rigidities of a puritan religion (125). This gospel of "self-reliance," preached by an author whom Miller sees as similar to Nietzsche in certain aspects, was associated with civil disobedience as a form of democratic politics. ${ }^{3}$ This phenomenon is portrayed affirmatively in the book, although with the caveat about the problem of "real political justice", with an accent put on the problem of racial discrimination. Namely, Miller observes how "nonconformism and defiant individualism can flourish while ... the quest to create a more inclusive democratic society languishes" (128). Whitman who, paradoxically (perhaps as Miller himself), saw the development of "perfect individualism" as the telos of democracy (130), "had exalted America's democracy as he had experienced it inwardly, as a kind of sublime pantheism, egalitarian in substance and cosmic in scope" (129). Miller acutely notes the interesting discrepancy between Whitman's hymns and the disgust he expressed in private letters with his "dark-skinned compatriots who were intoxicated by their first taste

3 To be sure, Nietzsche was no democrat at all. Socrates, Jesus, Luther and Rousseau belonged to the same democratic lot (die vier großen Demokraten; Nietzsche 1887a) as, in Nietzsche's equation, proponents of equality, epistemic or political, religious or secular. To him, democracy is a sign of societal decadence, a political form that is both an introduction to anarchy and an equivalent to misarchism, hate of the many for the natural rule of the few that have the will to power (Nietzsche 1887b). 
of political power" (130), the disgust similar to Miller's when he discusses historical cases of various politically ignited mobs, be it Athenians led by demagogues or blood-thirsty sans-culottes of the French Revolution. They seem to fit in Whitman's definition of "many wild brutes let loose" (130).

\section{VII.}

The fourth chapter, "A Struggle for Political and Social Equality," returns the narrative back to the old continent, dealing with the Chartists and the characters such as Marx, Mazzini, Michels and Weber. The first political group expectedly did not fare to well by Miller's standards, since they treated "the Jacobin constitution of 1793 as sacred scripture" and "idolized Robespierre" (135). Their "promises were, in a strong sense, democratic - but their methods were increasingly revolutionary and hinged on the actions of a relatively small minority of committed militants" (139). Marx is treated without awe, in the recognizable style Miller employed in the book about philosophers, dissecting their biographies in defiance to any mind-numbing sacralisation. Marx "felt that democracy was not an end in itself but only a means toward the ultimate aim of fully realizing human freedom in a peaceful society of equals" (142), and "he speculated that an economy organized on egalitarian principles would, eventually, be able to do without the hierarchical methods of command and control characteristic even of representative governments like that of the United States" (143). A history of Yugoslav self-management might add to this theme: long ago Miller was a fan of that literature but soon enough he got disenchanted with that "brand of cynical Marxism", as he explained to me in an e-mail. In any case, he still seems to be fond enough of Hegel and a connoisseur of the rationalist history of ideas which helps him delineate Marx from the shady milieu of secret societies, anarchist bombs and insurrections:

Marx abhorred the votaries of conspiratorial insurrection - Blanqui, Bakunin, the whole lot. Their secret societies and obsessive scheming offended his core rationalism and his (Hegelian) hope that the sharp, open conflict produced by truly popular social movements would produce, in time, and in the crucible of civil wars, new men and new women, equipped to establish a new world of emancipated, and enlightened, equals. (154)

Not surprisingly, the negative minor character here is Raoul Rigault, an outspoken atheist and revolutionary, master of the manipulative art of rhetoric and a bon-vivant, a small scale Robespierre of Paris Commune, a principal of police terror, executions and feasts, "legendary for his outlandish tabs (one breakfast after a long night supposedly consisted of two fine Burgundies and Chateaubriand aux truffes)" (153). Speaking of the good and the bad guys within this chapter, Miller seems to be much more congenial to Giuseppe Mazzini than to Marx. Mazzini, an Italian republican and one of the key characters in the unification of Italy, whom Marx understood as a reactionary, noticed the discrepancy between the egalitarianism of Christianity and the hierarchical nature of political societies. In Schmittian terms, it might be said that Mazzini offered a sort of political theology of democracy, deriving the principles of national politics from the sacral grounding premises of the Christian doctrine: "We cannot logically declare the children of God to be equal before God and unequal before men", he stated (145).

Opposing Marxism, Mazzini mused on the gradual change - the evolution of societies and human species, against the lethal revolutionary experiments such as 
Paris Commune. Miller seems to follow him, opposing the carnivals of violence. In Miller's meta-narrative that cuts across the historical episodes, they are associated with a formula of "delirious community of equals" (151). It is one of the possible succinct definitions of democracy Miller plays against. While I doubt that the party members from the buses in the introduction were delirious, they might still fall into this camp of democratic phenomenology, associated with temporary intoxicating moments of fraternity on various levels. It is Le Bon's material, often with lots of corpses on the barricades, similar to those beneath Delacroix's Liberty's nipple. However, Miller also notices a paradox of changes associated with bloody revolutions (a sort of historical dialectics, although he doesn't use such language): fear of violence and popular pressures bring up changes to political order, which is a point traditionally made by Marxists who tend to notice that violence is a midwife of the new order. In another paradox characteristic for a democratic believer, he seems to be abhorred with violence but still thrilled by the opportunity democratic moments bring to political history. In one of the possible readings, the ambivalences of democracy trump the quasi-Manichaeism of political actors spawned by the democratic moments and the liberal from the title of the essay perhaps appears more democratic than he is willing to admit, warts, populism and all.

Enter modern political parties, organizations unbeknownst to the Greeks. They open the questions of political form and content, partially intimated in the beginning of this essay: "Should a party that advocated democracy organize itself democratically? Did it matter if its rhetoric was revolutionary while its policies were reformist?" (159) Many figures appear in association to these problems, such as Eduard Bernstein and Rosa Luxemburg, rising broader issues about the relationship between socialism and democracy, as in the famous "genealogy" written by Laclau and Mouffe. However, the lead role belongs to Robert Michels, an observer of actual practices of social democracy that exemplified the discrepancy between socialism and democracy, equated in a naive idealist understanding of some of the proponents of socialism. Michels, under influence of Pareto and Mosca, was famous for his formulation of the iron law of oligarchy, which is in accord with their theory of elites that, as ever, successfully eschew nominally democratic forms. Miller rightly finds great interest in the longterm correspondence between Michels and Weber, "a priceless record of how two astute observers viewed the modern struggle for political and social equality, and the divergent ways they evaluated its prospects" (167).

Weber, a diagnostician of the fossilized Western civilization, explained to his young and still idealistic syndicalist friend, how Rousseauian notions of the will of the people are but fictions. If one does not to adhere to revolutionary ethics of the will, formally a secular variant of the Sermon on the Mount, as is Kant's categorical imperative, one must accept "the sociological conditions underlying all 'technologies,' be they economic, political, or whatever" (168-169), which makes talk of revolution a (farcical) utopian call. Weber's patronizing is not the whole story, assuming a recognizable form of a dialogue between an older (complacent) cynic and a younger (naive) idealist who will grow up (both of course bourgeois). An unexpected parallel emerges, accentuating another possible normative layer in Miller's complex narrative: "Weber could see the advantage of handing effective political power in avowed democracies to shrewd dema- 
gogues, just as Athens had handed power to Pericles, who was able, according to Thucydides, to harness productively the otherwise dangerous passions of unruly and uninformed citizens" (170). To put it differently, it comes down to good leadership (for Weber, this was paired with political ethics of responsibility) in "[t]he democratic currents of history", which "resemble successive waves" where, as Michels further observed, revolutionary leaders become the part of a new establishment to be in "turn attacked by fresh opponents who appeal to the name of democracy", which lead him to a somewhat mystical conclusion: "It is probable that this cruel game will continue without end" (172).

\section{VIII.}

The last of the chapters, "A Hall of Mirrors," is the first one with a composite metaphorical layer in the title, possibly referring not only to Versailles, but also to the structure of the chapter, where narrative jumps from America to Europe, from the United States to Russia. The chapter deals with Wilson and Lenin - the two champions of quite differently understood right of self-determination - with Bernays (a bad guy) and Lippmann and Dewey (the good guys). Moreover, the mirrors might also refer to the mirrors of democratic experience across history, which is repetitively portrayed in the book, in a sort of structure of fugue, where similar musical motifs are repeated and reworked as democracy as the rule of the people is, in new historical and geographical settings.

Wilson, a professor of politics at Princeton and university's president the first and thus far last American president with a $\mathrm{PhD}$, as Miller notices (174) - had a lofty vision of "a concert of democratic nations, each one established through a democratic process of self-determination", but Miller is also quick to notice his parochialism when Wilson deals with democracy in Europe, as well as his "white supremacist assumptions" (177). In the choice between natural aristocracy (Adams) and plebeian democracy (Jackson), Wilson is closer to the former option. During his times, one can observe the formation of a gap, very important in Miller's opinion, between the discourse of democracy and actual practices of governing, associated with the development of federal bureaucracy, the ambitious policing schemes and the imperatives of secrecy associated with the maintenance of national security. The Patriot Act is nothing new, in other words. It is a part of a century old American tradition. Together with Weberian concept of bureaucracy and the distinction between politics and administration (a founding moment of the Wilsonian science of administration), another Weberian uneasy motif appears. The Führerdemokratie shows up in Miller's narrative about Wilson, and he even sees Wilson's war speech as "a fine example of an eloquent demagogue in full oratorical flight" (181). "God helping her, she can do no other," Wilson concluded his speech, and Miller added: "The final, Protestant flourish is telling" (181). Indeed it is, as yet another example of Miller's analytical heed for the issues of political spirituality which I discuss at the very end, and of the normative complexity of the narrative where leadership appears both as necessary and dangerous for democracy. And that is another democratic aporia or antinomy (the reader may choose) a "tension" that continues the list offered in the abstract of the essay.

The account of Soviet experience is intertwined with biographic bits on Lenin, a strategist of a great willpower as described by Gorky (187). The result did not fare to well on the test of democratic evaluation: "in theory, a prole- 
tarian and peasant democracy; in reality, a new state ruled by one party, the Bolsheviks, and, ultimately, by one man" (189). It was a dictatorship, but this is not especially new or controversial finding. Much more interesting are Miller's discussions about the relationship between public opinion and democracy. The problem is not only in the biased media, the said secretive bureaucracy, and various manipulative political actors, but also in the stereotypes that influence the political thinking of the citizens. No wonder that Walter Lippmann appears as a skeptical hero in Miller's narrative. His analyses seem to put Enlightenment dreams of Condorcet \& co. to serious test, but one of the proposed solutions, setting hope on the "trained civil servants with an in-depth knowledge of the facts pertinent to formulating reasonable public policies" (201), is not unambivalently comforting (in the literature about critical policy analysis, which I happen to know quite well, this is criticized "technocracy"). In any case, Lippmann's well-known idealist counterpart, who with Wilson (and Miller) shared a vision of democracy, understanding it as "a matter of shared faith" (201), is James Dewey. Dewey's broad understanding of democracy infused Miller's initial answer with even more religious overtones. Democracy was "a kind of church writ large, a communion of souls sharing the same faith in freedom and equality and fraternity" (202). However, Miller is quick to see the problem. Dewey does not refute Lippmann empirically, as Miller's notices, and his skeptical face thus shows itself in an assessment of Dewey's visions: it's "Emerson and Whitman redux: democracy in America as a 'state of vision,' an elusive dream, a redemptive ideal, yet still worth struggling toward, even against the current of events" (203).
Edward Bernays, cherished as reverent figure, at least in the Croatian public relations milieu and establishments ${ }^{4}$, appears in a very negative light. Miller portrays him as a sort of a cynical manipulator in a post-truth world avant la lettre - the world, in Bernays' own words, of "the so-called truths by which society lives" which "are born of compromise among conflicting desires and of interpretation by many minds" (204). This also brings out yet another semantic facet to the title: "At Versailles, the Hall of Mirrors was a symbol of absolute power, with the long corridor of mirrors reflecting a controlled landscape that, seen through the windows on the other side, seemed to stretch to infinity. What Bernays had called the 'mirrors of the public mind' evoked not Versailles but a fun house maze" (205). Need it be said that this metaphor, evoking an older allegory of the cave, does not sound too good for democracy?

However, even if democracy often appears as a sham, especially when assessed by more ambitious criteria, Miller, still a skeptical proponent of Enlightenment (I think), sticks to the project, since even this "'sham"' "represents an epochal transformation": "the rulers of every contemporary regime that professes democratic values, however feebly realized, must periodically face the mundane threat posed by ordinary citizens, however uninformed, periodically queuing at a polling station, to exercise their right to vote, and so to transfer power, if they choose, to an entirely new set of political leaders" (211).

IX.

"The Coda" tries to provide an answer to Huntington's question of "Who are we?",

4 One private higher education institution in Zagreb bears his name: "Edward Bernays University College", offering degrees in communication as well as in tourism management. 
a question that much haunts Miller and other Americans for the last several decades. Miller, himself being involved in the activities of the anti-Trump opposition, offers a piece of prose reflecting the current political moment. However, the text is once again ironic and skeptical. In lack of a better interlocutor, old Miller speaks to the young Miller here, as Weber does to Michels. It is a testimony of a young leftist idealist who with age turned into a more conservative political adult. It is a political coming of age essay. To be sure, the portrait of Trump is not flattering. Miller doesn't seem to like him: "A cartoon of self-reliant cockiness, the candidate adored being the center of attention and, like a louche comedian, merrily defying the norms of civil discourse" (214). There is much more, but the point is in the wider picture Miller draws, transforming the recent American experience into another vignette in the history of democracy. Protesters against Trump on the streets of New York shouted "This is what democracy looks like!", but Miller, himself part of the crowd, was mature enough to understand the similar sentiments of their political opponents. He and his co-protesters felt as "people in a bitterly divided country feeling like strangers in their own land" (216), but so did many others after Obama's two successive elections: "Now it was my turn" (217), Miller observed. Moreover, he also understood that it was American identity at stake in these struggles, generating tensions and challenges for American democracy, and he turned to Samuel Huntington to look for the answers.

Rereading of Huntington today may appear as common sense, but it is a controversy at least in the New School milieu. What once angered the young Miller, became a set of "sensible observations" (217) for the old Miller. It is not capitalist economy but democratic politics producing conflict, Huntington fathomed in the 1970s, as Miller does now. Add to this Huntington's ominous implications that, as in some negative eschatology of political decadence, American democracy does not have the freshest outlook: that what seemed preposterous and absurd to young Miller now becomes sensible, namely the idea that perhaps "John Adams had been right to warn, almost two hundred years ago (roughly the life span of the Athenian democracy), that 'there never was a democracy yet that did not commit suicide"' (218).

Huntington is another prodigy in Miller's story, as Condorcet was in his times - a conservative who saw WestPoint as "a bit of Sparta in the midst of Babylon", a remark that, in one of Miller's ironical quips, disabled Huntington to teach at Harvard, at least right away, since he still ended there, at the richest and probably most prestigious American university, "after only five years in the wilderness, teaching at Columbia" (221). Huntington, perceived by the young leftists as a war criminal, had his portion of graffiti on his house (in a finer version of the similar political sentiment, Chomsky saw him as one of the mandarins of new American power). Skeptical and far-sighted in the realm of international relations, unlike his triumphant Hegelian student Fukuyama back in the early 1990s, Huntington saw the rise of power of China and Islamic world, leading him to conclude that reasonable (American) politics would have to eschew universalism (223), perhaps just another, finer name for the failed project of global empire. Parallel to his analysis of international relations, Huntington's last book dealt with American identity, providing the title to Miller's coda. In that book, Huntington tried to take into account "the long-term implications of demographic and cultural 
trends on America's sense of national identity" (224).

Miller's reading of Huntington, who back then saw prospects of "white nativism" in the United States, is not too reassuring for American democratic prospects. American identity, historically speaking, was not at all universal but more or less white, Anglo-Saxon protestant, paired with democratic ideology that produced conflicts (225). Political skeptics, and political believers with skeptical face such as Miller, recognize Huntington's historical lesson that political principles are not enough to keep the polity together. Huntington wasn't optimistic at all: "For Samuel P. Huntington at the end of his life, this is what American democracy looked like: a fragile ideology, with cloudy prospects" (226).

And Miller? A disappointed radical democrat of the 1960s, rooted his skepticism in personal political experience "my own experiments in radical democracy quickly fell apart, as my friends and I tired of the endless meetings and suppressed disagreements that the quest for consensus entailed" (228). The author of Can Democracy Work? is thus aware that the efforts such as the Occupy movement most probably will not produce a set of viable alternative institutions. The account of his own experience of direct democratic failures helps him to finally tie together the whole narrative about historical democratic episodes:

Instead of single-mindedly pursuing a new form of "collective thinking" through endless meetings meant to forge consensus - a quixotic and self-destructive goal that led astray the sans-culottes in 1793, the soviets in 1905 and 1917, and the New Left of the 1960s - I think we would do better to explore new ways to foster a tolerant ethos that accepts, and can acknowledge, that there are many incompatible forms of life and forms of politics, not always directly democratic or participatory, in which humans can flourish. This, in part, is what I understand by the aspiration to create a liberal democracy. (234)

The finale of the book is not too reassuring, offering parallels between radical democrats and populist leaders not protesting against democracy but against its limits. Dahl's and other comprehensive definitions of democracy, such as the one employed by the Varieties of Democracy project (V-Dem), include liberal components, and Miller reminds us that illiberal doesn't mean undemocratic. Ultimately, democracy, in the more mundane repetition of the introductory motif, emerges not only as a name or an ideology, but also as "a moral vision, of free institutions as a better solution to the problems of human coexistence than the authoritarian alternatives" (240), threatened today as the Enlightenment project championed by Condorcet and others. Secretive bureaucracy and PR operations manipulating public opinion, as in Habermas' early critique of contemporary public sphere, contribute to a world of "disinformation" loved by "suspicious, even paranoid" recipients (244). A bleak outlook, which still doesn't liberate Miller from his democratic faith: "however skeptically, and knowing that these words represent a riddle, not a recipe", he evokes "Abraham Lincoln's characteristically American hope, especially in the darkest of times: 'that government of the people, by the people, for the people shall not perish from the earth"' (245).

\section{$\mathrm{X}$.}

I am indeed not sure if the book ultimately solves the riddle of democracy. I am not even sure that author had such an intention, as the last lines suggest. Does 
it offer a clear and simple normative solution? Not quite. There is no "recipe". However, in the final assessment, it can be said that the book instead issues a reasonable skeptical warning and a sincere confession.

Can Democracy Work? offers a history of democratic and despotic episodes, a set of comparisons and parallels, empirically informed insights in the genre of history of ideas, biography and political history. It is penned by an old skeptic still wanting to believe in democracy, warning the reader of its pitfalls. It skillfully poses the problem of democracy, by warning about its dark side, its (auto) destructive force coming out of the unhealthy association of demagogues and mobs but it also offers some enthusiasm for the possibilities opened by the democratic vistas. In the end, Miller perhaps wrote a book that more resembles a repetitive fugue than to an evolving genealogy, a recollection of democratic episodes perhaps making a step forward in history with vague promises of collective freedom and empowerment, but too often mutating into destructive hecatombs. Since people seem to have passions and interests, and society is not and cannot be an impassioned scholastic seminar, as Miller's historical analysis exemplifies, Miller's more precise solution, as far as one can surmise, would not propose a Habermasian deliberative democracy for democracy to work. He seems to be quite clear about that. Generally speaking, he also doesn't seem to buy the story of positively reevaluating populism, a taming of the notoriously violent Schmittian political proposed by Laclau and Mouffe. As he seems to abhor the occasional cruelty of the masses, or doesn't see the constructive point in the direct democratic discussions, he as well despises the facility of armchair philosophy dealing with democracy, ignoring its real historical dynamics.
Capitalism is also not the one to blame. Miller seems to follow Huntington in putting democracy first in some situations: democracy is the cause, not the effect. Unlike some other New School professors, like Nancy Fraser, he does not muse against progressive liberalism. (He may well be one of them progressive liberals - a Deweyan optimist.) As Rousseau himself, Miller is not a theorist of political economy. The story about hegemonic bloc associated with the destruction of the middle class, to be politically assailed with justice as recognition and (re)distribution (from the academic corridors), is simply not his cup of tea. He is no social justice warrior as, on the other hand, a vision of democracy as a militaristic ethnic nativist band of brothers is as far as possible from his normative universe of the true and the good. Moreover, it seems to me that Miller doesn't attempt to solve the riddle by the means of a theory of distributive justice: the problem of who should get what and when - and how this should be solved, e.g. by market, love, religion, war, struggle, collective will (or whatever) - is not his problem. As he is no Rawls, he is no Alasdair MacIntyre. He doesn't seem to have a substantive telos in the sense of a "comprehensive doctrine". He is a liberal. His darling metaphor is hijacking: democracy is hijacked by the bad guys, violent fanatics or simply sadists. It's an old threat lurking from the Greek times when democracy sentenced Socrates to death, suggesting it can become a bigger tyranny than any oligarchy. Can Democracy Work? is in that sense also a story of various hijackers destroying liberal protections far beyond the episodes of civic or intraparty disobedience, employing buses or provisional protest tents.

However, all that said, Miller still professes a democratic faith in the tradition of Whitman and Dewey. He shares a picture with them of a democratic cul- 
ture, maybe hopelessly intertwined with liberalism, perhaps a telos itself, elusive and uncertain, as Whitman's visions. This is not a forced reading. Albeit the skeptical irony and self-awareness of ethnocentric, even idiosyncratic nature of this faith, or perhaps any faith, Miller's democratic belief is clearly expressed. It is a paradox of credo quia absurdum. With a reference to Whitman and a question mark, Miller still sees democracy as "future-oriented" (10), as any faith is, and starts his story with a rational reflection upon his political faith: "it is also a deeply personal narrative, if only because I am inescapably the product of a typically modern democratic faith that was drummed into me from birth. This makes it hard for me to draw a sharp line between my considered political beliefs and an internalized ideology that, in fact, typifies the present age" (12).

It then remains to be answered at the end of this essay what is the nature of this faith, surviving even the dark finale of the book? It is perhaps something typically American, as Miller again admits at the very end. There is historical and personal dimension to this question of faith. In the third chapter, Miller reminds the reader that Tocqueville saw "America's political piety at work", observing a "civic religion, rooted in a Protestant form", a species of democratic and republican Christianity: he understood this as a moderating factor, "a brake on the potential wildness of self-reliant self-rule" (115). However, when bereft of pathos, a much bleaker outlook of a tyranny, not of state but of society, could emerge, following another Tocqueville's insight. Instead of a societal culture working against political tyranny, one can imagine a society self-satisfied and unaware of its own potential for tyranny, quite zealous to uphold to its tradition of witch hunts. It need not be religious: a secularized puritanism will easily find new witches to hunt. In other words, a democratic society may not constitute a brake but a fuel for the fire of despotism. This is not problem that, in my opinion, preoccupies Miller seriously enough. Be it as it may, a historical sociology of political religions could tell a part of the story about this democratic faith since the sources of the self are historical, cultural and political. And the personal dimension of the faith?

Miller is not shy about it. When he writes of Mazzini, "[t]he child of a Jacobin father and a Jansenist mother" who "tried to reconcile the democratic principles of his father with the austere faith of his mother" (145), it almost reads like an oblique autobiographic reference. On the one side, it's the story of the father, not a fully-fledged Jacobin to be sure, but an academic expert on Whitman. Miller was "raised to revere Walt Whitman" whose "strange vision" of democracy, in Miller's interpretation, becomes "a prophecy, a voice raised to keep faith with a future to which our shared past has committed us", and "a supreme fiction," with a reference to elusive "orgastic future" from Fitzgerald's The Great Gatsby: "But this is what democracy in America often seems like: an elusive fantasy, forever out of reach, forever unrealized, even as its most eloquent bards, trapped in their own prejudices, are 'borne ceaselessly back into the past"' (131). And how can we reach the author's mother? If the book has a prelude and a coda, Dewey is, musically speaking, the bridge between democracy and religion, leading us to the part of the story about the mother. Miller writes about Dewey's "disarming candor"; Dewey was a philosopher of democracy, but "explicit about the religious motives behind an ostensibly scientific theory", claiming that the next prophet who will 
succeed "in pointing out the religious meaning of democracy" (202).

On the other side of this Deweyan bridge, we can then see how the mother sets the tone. She provides the spirit to infuse the democratic form with a religious belief, as Dewey tried to do. Miller writes: "And I was taught that I had a duty (my mother believed it was God-given) to make this exceptional society an even better place, in part by exercising my political rights, not only to vote but also to think for myself and to speak out against perceived injustices" (7). Democracy is a moral duty in the historical struggle for justice. But will the good prevail in this Manichean story that suddenly acquires an almost eschatological telos? An anecdote may help here. I remember how, after a symposium in his apartment, Miller pointed to the apocalyptic illustrations in a reprinted $16^{\text {th }}$ century Lutheran Bible, and exclaimed, perhaps ironically: "These are my people". ${ }^{5}$ Democratic faith, in this strange perspective, appears like a political sublimation of a mysterium coniunctionis, a mystical synthesis of the opposites in the familial tree of life: "father" and "mother," bringing together hope for democracy with some hints of a dark eschatology. A secularized faith in liberal democracy is still religious in its spiritual core.

5 In case the reader is still wondering how come I wrote such a lengthy essay concerning yet another book on democracy: I've spent two autumn semesters as a visiting scholar at the New School. Miller was my academic host, I read the book before publication and I am credited in the acknowledgments. If there was a Dionysian socialism, referring to the fact that Praxis school philosophers and their German colleagues periodically discussed the intricacies of "Being" with the little help of red wine, Miller's symposia can perhaps be described as a species of Dionysian liberalism. No wonder that they did not take place on Korčula or in Dubrovnik, but in a small Manhattan apartment crammed with books and CDs.
Albeit all the skepticism, Miller is still able to project hope on the American democratic project. He warns us, associating this with Wilson's understanding of democracy, that democracy rests on public opinion as do the interpretations of no less than our "deepest moral and political convictions": "Unlike Martin Luther, Woodrow Wilson was taking a stand on shifting sands" (182). That may be the most important single sentence in the whole book. It points to the riddle of democratic faith. How can one believe when a history of collective visions of justice and good life of Rousseauians giving themselves to each and every other citizen at the same time, and thus in theory not giving oneself to no one, looks like a history of those foolish enough to give themselves to demagogues and despots, witch-hunts and propaganda? In other words, what a strange faith, to entrust oneself to the whims of a historical political mechanism built on shifting sands, certainly not stranger than a belief in God. To justify the belief in democracy with its record of hecatombs becomes almost a theodicy, an old and demanding spiritual sport of justifying the belief in God in spite of all the suffering in the history of the world.

Unlike Ken Toole's Ignatius Reilly, lamenting on the horrors of decadence brought about by democracy in America, there are those still dreaming, at least because they cannot see a viable alternative, as the theodicies have no choice but to accept this world with all its horrors. This is the book for them. It is not a condemnation of a farcical "confederacy of dunces" but an exercise in political spirituality. It espouses a belief in democracy after all - a belief which is, to be sure, bereft of all rationalistic protection of the American reception of French Hegelianism. It is a pure profession of faith in the dark times. It is 
neither Kojève's history vindicating its own rationality, as Fukuyama, a recent theorist of political decay, ended his still most famous book, nor a sad time from the vantage point of political boredom, as he intimated earlier in his famous article. The wedding of a historical Weltgeist and American democracy has ended up in a divorce. The ambitions of
Can Democracy Work? are thus much more modest. It is a testimony of a fragile democratic faith in the times of Huntington's clash. The sympathetic readers may only hope that democracy will prevail and that the clash will not turn into a tangible apocalypse prophesized by religious eschatologies as depicted in an illustrated Lutherbibel.

\section{References}

Miller, James. 1984. Rousseau: Dreamer of Democracy. New Haven: Yale University Press.

Miller, James. 1994. Democracy is in the Streets. Cambridge, MA: Harvard University Press.

Miller, James. 2012. Examined Lives: From Socrates to Nietzsche. New York: Picador.

Miller, James. 2018. Can Democracy Work? A Short History of a Radical Idea from Ancient Athens to Our
World? New York: Farrar, Straus \& Giroux.

Nietzsche, Friedrich. 1887a. Fragment from Autumn 1887 (group 9, no. 25). http://www.nietzschesource.org/\#eKGWB/NF-1887,9[25]. Accessed October $15^{\text {th }} 2018$.

Nietzsche, Friedrich. 1887b. Zur Genealogie der Moral: Eine Streitschrift. Leipzig: C. G, Neumann. http://www. nietzschesource.org/\#eKGWB/GM. Accessed October $15^{\text {th }} 2018$ 


\section{Kako to da liberal još uvijek vjeruje u demokraciju? Zagonetka politike i vjere}

Povodom knjige Jamesa Millera

Može li demokracija biti djelotvorna?

Kratka povijest radikalne ideje od antičke Atene do danas

New York: Farrar, Straus \& Giroux, 2018.

Sažetak Ovaj se kritički esej bavi knjigom Može li demokracija biti djelotvorna? Jamesa Millera koja, upozoravajući na probleme demokratske politike, zadržava demokratsku vjeru. Kombinirajući političku znanost i historiografiju te ispreplećući povijest ideja i političke biografije u prikazu različitih epizoda u povijesti demokracije, knjiga nastoji dati uvid u zagonetku demokracije. Ta se zagonetka pokazuje u različitim teorijskim i praktičkim napetostima: između rusoovskog zahtjeva za suverenošću naroda i općenite volje s jedne strane te platonističke epistemičke skepse prema sposobnosti naroda da odlučuje i političkih zahtjeva liberalizma s druge strane; između potrebe za kontrolom vladajućih i političkoekonomske dinamike korupcije i klijentelizma koju potiče demokratska politika; između pobuna protiv elita kao nekovrsne političke higijenske funkcije poretka i neizvjesnih ishoda koje donosi inherentna nestabilnost i sklonost demokracije ekscesima te između izgledne nezaobilaznosti izbora i njihove kooptacijske zamke. Između liberalizma straha na tragu Judith Shklar i populističkog uzbuđenja na tragu Chantal Mouffe, autor zadržava demokratsku vjeru - političku inačicu kjerkagorovskog egzistencijalizma koji stupa s onu stranu neodlučne, vječito sumnjajuće refleksije i političko dobro koje se dijeli s drugima, unatoč svim neizvjesnostima javnog mnijenja i dokazane upitnosti građanske vrline u otvorenom polju političkog u povijesti.

Ključne riječi demokracija, liberalizam, zagonetka, genealogija, populizam, javno mnijenje 
